\title{
IDEN'TIFICATION OF A CELL SURFACE GLYCOPROTEIN FAMILY OF OLFACTORY RECEPTOR NEURONS WITH A MONOCLONAL ANTIBODY ${ }^{1}$
}

\author{
W. K. ALLEN AND RICHARD AKESON ${ }^{2}$ \\ Division of Cell Biology, Children's Hospital Research Foundation, University of Cincinnati, Cincinnati, Ohio 45229
}

Received December 27, 1983; Revised June 18, 1984; Accepted July 19, 1984

\begin{abstract}
A monoclonal antibody (Mab) has been developed which recognizes a family of cell surface glycoproteins found in high levels of rat olfactory receptor neurons. This Mab, designated 2B8, was produced by the fusion of X63-Ag8.653 myeloma cells and spleen cells of a mouse immunized with PC12 rat pheochromocytoma cells. Immunofluorescence analyses of cryostat sections of neonatal olfactory epithelium show prominent 2B8 binding to receptor neurons. Within the olfactory bulb only the glomerular and olfactory nerve layers show $2 \mathrm{~B} 8$ binding. All other neural structures in the main olfactory bulb have background levels of reactivity. Analyses of $2 \mathrm{~B} 8$ hinding to particulate protein preparations from several central and peripheral nervous system components demonstrated highest 2B8 antigen specific activity in olfactory bulb and epithelium and detectable levels in dorsal root ganglia (DRG), whole cerebrum, cerebellum, and brainstem. However, 2B8 antigen could not be detected in non-olfactory structures by immunofluorescence. Some non-neural tissues also had the ability to bind 2B8 Mab in the particulate protein radioimmunoassay. In order to compare the $2 \mathrm{~B} 8$-reactive molecules found in each tissue, Mab was applied to polyacrylamide gels of unlabeled membrane proteins. A family of molecules with diverse molecular weights was found. Some were unique to individual tissues whereas others were shared among tissues. Olfactory bulb and epithelium had a unique band with $M_{\mathrm{r}}=215,000$ and another band with $M_{\mathbf{r}}=142,000$. The 142,000-daltun band was also found with PC12 cells. PC12 cells also had several bands of lesser molecular weight, including 51,000 and 43,000. Testes membranes had immunoreactive bands only at $M_{\mathrm{r}}=46,000$ and 43,000 . Bone marrow, perinatal liver, and DRG each expressed a single 2B8-reactive band with $M_{\mathbf{r}}=\sim 114,000$. Salivary gland had four reactive bands, two common to it and only PC12 cells, the 114,000-dalton band which is similar to that found in adult rat bone marrow and DRG, and a unique band at $M_{\mathrm{r}}=152,000.2 \mathrm{~B} 8$ immunoprecipitates of olfactory bulb and epithelium were analyzed for glycosyl groups by lectin reactivity. Wheat germ agglutinin and Ricinus communus agglutinin I bound the $2 \mathrm{~B} 8$ antigens using two distinct assay methods. This suggests that the $2 \mathrm{~B} 8$ antigens recognized in the olfactory system are glycoproteins having sialic acid and D-galactosyl components.

In summary, the $2 \mathrm{~B} 8 \mathrm{Mab}$ recognizes a group of glycoproteins which are the first identified cell surface components of olfactory receptor neurons. $2 \mathrm{~B} 8$ immunofluorescence reactivity in the nervous system is found only on cells of the olfactory system. Although non-neural tissues have $2 \mathrm{~B} 8$ immunoreactivity, the molecules recognized differ in apparent molecular weight from those detected in olfactory structures.
\end{abstract}

In the study of the nervous system, cell-type specific markers are very useful. Cell surface components are believed to be important in cell recognition and other interactions occurring during neural development, including cell migration and neuronal process and synapse formation. Therefore, an immunological approach has been taken in this laboratory as well as others to identify nervous system-specific cell surface antigens

\footnotetext{
${ }^{1}$ We would like to thank Dr. Daryl Doyle (P3-X63-Ag8.653), Dr. Lloyd Greene (PC12), and Dr. David Schubert (B35) for cell lines. Dr. Michael Shipley initially suggested and provided guidance in the analysis of olfactory tissue. Technical assistance was given by Ms. S. Warren and Ms. S. Arnold. Ms. Maureen McCarthy provided cxcellent secretarial assistance. This work was supported by National Institutes of Health Grant NS-13241.

2 To whom correspondence should be addressed.
}

(Brackenbury et al., 1977; Akeson, 1979; Bock et al., 1980; Stallcup, 1981; Langley et al., 1982; Schachner, 1982; Stuhlfauth and Seeds, 1983). Although a number of nervous systemspecific monoclonal antibodies (Mabs) ${ }^{3}$ have been developed, only a few are specific to a subclass of neuronal cells. Among these are Mabs which bind to cell surface components of CNS but not PNS neurons (Cohen and Selvendran, 1981; Akeson

\footnotetext{
${ }^{3}$ Abbreviations used in the text are: Con A, concanavalin A; DBA, Dolichos biflorus agglutinin; DMEM, Dulbececco's modified Eagle's medium; D-PBS, Dulbecco's phosphate-buffered saline; DRG, dorsal root ganglia; FCS, fetal calf serum; HBSS, Hanks' balanced salt solution; Mab, monoclonal antibody; NP-40, Nonidet P-40; OMP, olfactory marker protein; RCA, Ricinus communis agglutinin I; RXMIg, rabbitanti-mouse IgG; SBA, soybean agglutinin; VNO, vomeronasal organ; WGA, wheat germ agglutinin.
} 
and Warren, 1982), as well as the reciprocal distribution (Vulliamy et al., 1981), to retinal photoreceptor cells (Barnstable, 1980), and to cat CNS neuronal subclasses (McKay and Hockfield, 1982).

We have developed an Mab, 2B8, which binds to cell surface antigens on primary sensory neurons of the olfactory system. $2 \mathrm{~B} 8$ is the first reported Mab which recognizes this subclass of neurons. An Mab to the supporting cells of the olfactory epithelium has been reported (Hempstead and Morgan, 1983). The olfactory system is a particularly interesting neuronal system for at least three reasons. First, in mammalian olfactory epithelium, there is believed to be a continuous replacement of receptor cells (Moulton et al., 1970; Graziadei and Monti Graziadei, 1978). Olfactory function is maintained while a continuous process of cell death, proliferation, neurite outgrowth, and synapse formation is occurring. Additional markers for precursor cells and mature neurons would be useful in studying this unique maintenance of function during turnover and also embryonic development of the olfactory receptor neurons. Second, the transfer and processing of information after the initial receptor neuron odorant recognition are not well understood. Specific odorants cause enhanced neuronal activity in specific olfactory bulb glomeruli which contain synapses from stimulated primary receptor neurons (Sharp et al., 1975; Stewart et al., 1979; Greer et al., 1981). Although some topographical specificity exists between receptor cells in the olfactory epithelium and their axonal projections in the bulb, particularly the relative distribution in dorsal-ventral directions, projections of small patches of receptor cells to the bulb are diffuse (Freeman, 1974). Mechanisms of olfactory information procesing in other areas of the CNS are also unknown. Of basic concern is the lack of information on the number and distribution of odorspecific neurons in the olfactory epithelium. An Mab which recognizes only a subset of receptor cells could be useful in investigating the projections of receptor neuron axons to the olfactory bulb. A third area of interest is the molecular basis of odor discrimination. Does the ability to discriminate a large number of stimuli lie at the level of the individual receptor molecules, as in the immune system where a great number of different $B$ cells with specific cell surface immunoglobulins can be found? Mabs which recognize cell surface odorant receptor molecules would be invaluable in understanding the early stages of olfaction.

This paper introduces an Mab which recognizes a putative cell surface marker for olfactory receptor neurons. Although the 2B8 Mab recognizes cell surface molecules of several rat tissues, the antigens are dissimilar, as inferred from diverse molecular weights. In the olfactory system two major bands are detected, one of which has a unique molecular weight and the other a molecular weight identical to that of an antigen recognized on PC12 pheochromocytoma cells. Reported here are the radioimmunobinding and immunofluorescence analyses of $2 \mathrm{~B} 8$ Mab reactivity and molecular characterization of the 2B8 antigens in rat tissues. Portions of this work have appeared in preliminary form (Allen and Akeson, 1983).

\section{Materials and Methods}

Cell lines. PC12 cells were maintained in Dulbecco's modified Eagle's medium (DMEM; MA Bioproducts) containing $10 \%$ horse serum (GIBCO) and $2.5 \%$ fetal calf serum (FCS; Reheis, Armour Pharmaceutical). All other cell lines-X63-Ag8.653, C6, B35, B16, S91, N18, CCl 49 , and NG108-were maintained in DMEM containing $10 \% \mathrm{FCS}$ (Reheis).

Animals. BALB/c mice (Jackson Laboratories) were used for immunization and the production of Mab containing ascites fluid. Rat tissues for particulate protein preparations were taken from SpragueDawley rats (Harlan). Rats used for olfactory system cryostat sections were less than 15 days of age.

Immunization, fusion, and screening. $\mathrm{BALB} / \mathrm{c}$ mice were each im- munized three times at 2 -week intervals with an intraperitoneal injection of 2 to $3 \times 10^{6}$ PC12 cells and a fourth time 3 days before fusion with an intravenous injection. Two mice with the highest titers of antiPC12 antibodies were sacrificed, and their spleens were minced and dissociated through a 40 mesh stainless steel screen. The spleen cells were fused with X63-Ag8.653 mouse myeloma cells using $40 \%$ polyethylene glycol (Galfre et al., 1977) and aliquoted at 1 to $2 \times 10^{5}$ myeloma cells/well in 96 flat-bottom well cluster plates (Costar) which were preplated with 6000 peritoneal exudate cells/well.

After 2 weeks of growth, the hybridoma supernatants were assayed for specific anti- $\mathrm{PC} 12$ reactivity. The primary screen of culture supernatants, with $5 \times 10^{4} \mathrm{PC} 12$ cells plated on poly-l-lysine (Banker and Cowan, 1977; Sigma Chemical Co.)-coated MicroTest III (Falcon) plates, was performed using a $\beta$-galactosidase-conjugated sheep-antimouse IgG second antibody and $p$-nitrophenylgalactopyranoside enzyme substrate (Bethesda Research Laboratories). To eliminate from further analysis any general mouse-anti-rat Mabs, media positive in the above assay were next tested for reactivity with rat tissue particulate protein from two to three non-neural tissues. Wells in which media did not bind to more than one non-neural tissue were dilution cloned on peritoneal exudate feeder layers. Mab-producing cell lines were maintained in DMEM containing 20\% FCS (Reheis), $0.1 \mathrm{mM}$ hypoxanthine, and $0.016 \mathrm{mM}$ thymidine for the production of media containing Mab and injected into Pristane (Aldrich Chemical Co.)-primed BALB/ $c$ mice for the production of ascites fluid containing Mab. Mab 2B8 was found to be an $\operatorname{lgG} 3, \kappa$ using immunoglobulin class-specific ant isera (Miles Laboratories).

Preparation of particulate protein and cells for assays. Adult and fetal rat and mouse tissue particulate proteins were prepared by homogenizing fresh tissues in a Dounce homogenizer and washing three times with iso-Tris $(10 \mathrm{mM}$ Tris- $\mathrm{HCl}, 140 \mathrm{mM} \mathrm{NaCl}, 0.15 \mathrm{mM} \mathrm{CaCl}, 0.5 \mathrm{mM}$ $\mathrm{MgSO}_{4}$ at $\mathrm{nH} \mathrm{7.4)}$ by centrifugation at $20,000 \times \mathrm{g}$ for $10 \mathrm{~min}$. The pellets were resuspended in iso-Tris and assayed for protein content by the method of Lowry et al. (1951). Cell lines were prepared by scraping from the plate and washing three times in iso-Tris by centrifugation at $200 \times g$ for $5 \mathrm{~min}$. Rat and mouse spermatozoa were collected from portions of the reproductive tract by mincing in iso-Tris, allowing to settle for $5 \mathrm{~min}$, and then collecting the upper $8 / 10$ of the tube. They were then washed three times in iso-Tris by centrifugation at $750 \times g$ for $5 \mathrm{~min}$.

Preparation of $\mathrm{F}\left(\mathrm{ab}^{\prime}\right)_{2}$ fragments. Tissues containing immune system components, including bone marrow, lung, spleen, thymus, and fetal liver, were assayed for $2 \mathrm{~B} 8$ binding with $\mathrm{F}\left(\mathrm{ab}^{\prime}\right)_{2}$ fragments to eliminate nonspecific binding of the $F_{c}$ portion of the $\operatorname{IgG}$ molecules. F $\left(a b^{\prime}\right)_{2}$ fragments were prepared from the ammonium sulfate precipitate of ascites fluid containing 2B8 or control Mab by digestion with pepsin at a protein-to-enzyme ratio of 1000:1 (Williams and Marchalonis, 1977). The $F\left(a b^{\prime}\right)_{2}$ fractions were collected from a G-200 Sephadex columu.

Antibody binding assays. Antibody binding to cells or particulate proteins was assayed by radioimmunobinding using a ${ }^{125} I$-protein A 15 to $15 \times 10^{6} \mathrm{cpm} / \mu \mathrm{g}$; Pharmacia) or affinity-purified ${ }^{125} \mathrm{I}$-rabbit-antimouse IgG (RxMIg) (heavy and light chain specific, 1 to $10 \times 10^{6}$ $\mathrm{cpm} / \mu \mathrm{g}$; Cappel Laboratories) second reagent (Akeson and $\mathrm{Hsu}, 1978$ ). Particulate protein $(50 \mu \mathrm{g})$ or $10^{5}$ cells and predetermined excess $\mathrm{Mab}$ from ascites fluid of mice carrying 2B8 or nonreactive Mab tumors were incubated for $60 \mathrm{~min}$ in $0.5 \%$ bovine serum albumin in iso-Tris (BSA buffer) containing $1 \% \mathrm{FCS}$ in a total volume of 100 to $200 \mu \mathrm{l}$. The unbound Mab was removed by layering the mixture over $1.0 \mathrm{ml}$ of $0.32 \mathrm{M}$ sucrose, $1 \% \mathrm{FCS}$ in $10 \mathrm{mM}$ Tris $\mathrm{HCl}, \mathrm{pH} 7.4$, and centrifuging at $16,000 \times g$ for $10 \mathrm{~min}$. The tissue pellet was dissociated by vortexing, and ${ }^{125} \mathrm{I}$-protein A or ${ }^{125} \mathrm{I}$-RxMlg in predetermined excess was added for 20 or $60 \mathrm{~min}$, respectively. Tissue samples were then washed free of unbound ${ }^{125} \mathrm{I}$-labeled reagent on a fresh sucrose cushion by centrifugation in a fresh tube as described above. The bottom of the tube containing the tissue pellet was cliped and counted in a Beckman Gamma 8500 counter at approximately $66 \%$ efficiency.

Immunofluorescence analyses of cells. Cell lines were plated at $10^{\circ}$ cells on poly-L-lysine-coated glass coverslips. Fxcess Mab (1:200 Mab ascites in $2 \% \mathrm{FCS}$ in BSA buffer at $200 \mu \mathrm{l} /$ coverslip) was added for 90 min at room temperature. Unbound antibody was removed by gentle swirling in three consecutive beakers of $50 \mathrm{ml}$ of Hanks' balanced salt solution (HBSS). The cells were then fixed with freshly prepared $2 \%$ paraformaldehyde (J. T. Baker Chemical Co.) in HBSS for 20 min and washed as above. Rhodamine-conjugated RxMIg (Miles; 1:30 in 2\% 
FCS in BSA buffer) was added for $90 \mathrm{~min}$. The coverslips were washed, the last time in iso-Tris, and mounted in F'A mounting fluid (Difco Laboratories). Slides were examined with a Zeiss ICM 405 inverted microscope equipped with $100-\mathrm{W}$ mercury lamp, immersion objectives, and filters necessary for fluorescence microscopy.

Localization of the 2B8 antigen on the cell surface of spermatozoa and bone marrow cells was done by immunofluorescence labeling in suspension. Spermatozoa were fixed immediately after isolation with $2 \%$ paraformaldehyde in HBSS for $20 \mathrm{~min}$. It had previously been determined that $2 \%$ paraformaldehyde prefixation did not significantly alter 2B8 binding to sperm, $\mathrm{PC} 12$ cells, or rat brain particulate protein. They were washed three tmes with HBSS by centrifugation at $750 \times g$ for 5 min. Labeling times and concentrations of reagents were as described for plated cells. After the final wash in iso-Tris and centrifugation, the cells were resuspended in FA mounting fluid and mounted between slides and coverslips. Bone marrow cells were labeled in the same way except that centrifugation was at $200 \times g$ for $5 \mathrm{~min}$.

Immunofluorescence analysis of cryostat sections. Tissue samples were removed and immediately fixed at room temperature in $2 \%$ paraformaldehyde, $0.32 \mathrm{M}$ sucrose in HBSS for $4 \mathrm{hr}$ and then soaked in $0.32 \mathrm{M}$ sucrose in HBSS for $4 \mathrm{hr}$. The tissue was frozen in liquid $\mathrm{N}_{2}$ and cut into $10-\mu \mathrm{m}$ sections which were melted onto $0.05 \%$ chromalum $/ 0.5 \%$ gelatin-coated slides. Diluted Mab solution (1:200 Mab ascites in $4 \%$ FCS in BSA buffer) was preabsurbed for 30 min wilh 0.5 to $1 \mathrm{mg} / \mathrm{ml}$ of adult rat kidney particulate protein. Sections were incubated $90 \mathrm{~min}$ with 50 to $100 \mu \mathrm{l}$ of $\mathrm{Mab}$, then washed three times with BSA buffer containing $2 \% \mathrm{FCS}$. 'To reduce any residual aldehydes, the sections were then incubated 10 min with freshly prepared $0.5 \%$ $\mathrm{NaBH}_{4}$ in Dulbecco's phosphate-buffered saline (D-PBS) without $\mathrm{Ca}^{2+}$ and $\mathrm{Mg}^{2+}$ at $\mathrm{pH}$ 8.0. Sections were washed, and then rhodamineconjugated RxMIg (affinity purified) was added for $90 \mathrm{~min}$. The second reagent (Miles) was purified before use by adsorption to an affinity column of mouse IgG-conjugated Affi-gel 10, elution with $3.0 \mathrm{M}$ potassium thiocyanate, and dialysis against iso-Tris. Preabsorption of the Mab and affinity purification of the second reagent reduced background fluorescence substantially. The sections were washed three times, the last time in iso-Tris, and mounted in FA buffer.

$M a b$ binding to electrophoresed peptides. 2B8 antigens were detected and compared in PC12 cells, olfactory bulb, olfactory epithelium, bone marrow, newborn liver, dorsal root ganglia (DRG), cerebellum, testis, and salivary gland membrane extracts with a gel-immunobinding method (Burridge, 1976; Rostas et al., 1977). Tissue particulate proteins were prepared as described previously except that protease inhibitors were added in the homogenization step and first iso-Tris wash. Unlabeled membrane extracts were prepared by solubilizing tissue particulate proteins in Laemmli sample buffer (Lacmmli, 1970) and boiling for $3 \mathrm{~min}$. The extracts were electrophoresed on $8 \%$ SDS-polyacrylamide gels at 50 to $100 \mu \mathrm{g}$ of protein/lane. The gels were fixed and then neutralized in iso-Tris overnight. $2 \mathrm{~B} 8$ antigens were detected by direct application to the gels of the Mab (1:100 Mab ascites in 2\% FCS in BSA buffer), followed by ${ }^{125}$ I-protein A $\left(3 \times 10^{7} \mathrm{cpm} / \mu \mathrm{g}\right.$; used at $10^{8}$ $\mathrm{cpm} / \mathrm{ml}$ in $20 \%$ FCS in BSA buffer). Gels were incubated with reagents for 8 to $15 \mathrm{hr}$ and washed in $0.1 \%$ Triton X-100 (Research Products International) in iso-Tris without $\mathrm{Ca}^{2+}$ and $\mathrm{Mg}^{2+}$ for 3 days following each incubation. The gels were then dried and autoradiographed. Similar gel-immunobinding experiments were performed on SDS gels of 2B8 immunoprecipitates of unlabeled olfactory membranes. The immunoreactive bands were visualized by application of fresh $2 \mathrm{~B} 8 \mathrm{Mab}$ and ${ }^{125} \mathrm{I}$-protein A. The $2 \mathrm{~B} 8$-reactive bands of total olfactory membranes and immunoprecipitated olfactory membranes were identical (cf. Figs. 5 and 6).

Lectin binding to $2 \mathrm{~B} 8$ antigens. To determine whether the 2B8 antigens in olfactory bulb and epithelium have covalently bound carbohydrate, immunoprecipitates were tested for lectin reactivity. Tissue particulate proteins for immunoprecipitation were solubilized in $1 \%$ Nonidet P-40 (NP-40; BRL) and protease inhibitors $(100 \mu \mathrm{g} / \mathrm{ml}$ of leupeptin, Transformation Research Incorporated (TRI); $100 \mu \mathrm{g} / \mathrm{ml}$ of chymostatin, TRI; $1,000 \mu \mathrm{g} / \mathrm{ml}$ of trasylol, FBA Pharmaceuticals; and $10^{-5} \mathrm{M}$ phenylmethylsulfonyl fluoride, Sigma) in iso-Tris for $20 \mathrm{~min}$. Insoluble material (mainly nuclei) was removed by centrifugation at $16,000 \times g$ for $15 \mathrm{~min}$, and the supernatant was preabsorbed two times for 10 min with Pansorbin (fixed Staphylococcus aureus; Calbiochem). In control experiments with olfactory tissues, the NP-40-insoluble fraction did not show significant $2 \mathrm{~B} 8 \mathrm{Mab}$ binding. Adsorbed NP-40soluble samples were mixed with $5 \mu \mathrm{l}$ of $\mathrm{Mab}$ ascites fluid, $10 \mu \mathrm{l}$ of
FCS, and BSA buffer in a total volume of $1.0 \mathrm{ml}$ and incubated for 60 min. The antigen-antibody complexes were precipitated with 50 to 100 $\mu \mathrm{l}$ of Pansorbin. The precipitate was washed two times with $0.1 \%$ NP40 in BSA buffer and one time with $0.1 \%$ NP-40 in iso-Tris by centrifugation at $16,000 \times g$ for $5 \mathrm{~min}$. The pellet was then resuspended in 100 to $150 \mu$ l of Laemmli sample buffer (Laemmli, 1970) and boiled $5 \mathrm{~min}$. The samples were centrifuged $15 \mathrm{~min}$ at $16,000 \times \mathrm{g}$, and the Laemmli sample buffer was replaced with $0.2 \% \mathrm{NP}-40$ in D-PBS by dialysis. The 2B8 immunoprecipitate was then adsorbed with either concanavalin A (Con A)-, Dolichos biflorus agglutinin (DBA)-, Ricinus communis agglutinin I (RCA)-, wheat germ agglutinin (WGA; all E-Y Laboratories)-, or soybean agglutinin (SBA; Vector Laboratories)-conjugated agarose beads or control Bio-Gel A-5m beads (unconjugated; Bio-Rad Laboratories). RCA bead adsorptions were also performed in the presence of $0.1 \mathrm{M} \mathrm{D}$-galactose (Sigma), and WGA adsorptions were performed in the presence of $0.1 \mathrm{M} \mathrm{N}$-acetylglucosamine or $N$-acetylneuraminic acid (Sigma). The 2B8 antigens remaining after adsorption were separated by PAGE and detected by direct application of Mab and ${ }^{125}$ I-protein $A$ to the gel as described above. The gels were dried and exposed on autoradiography film, which was scanned with a spectrodensitometer (Schoeffel, SD 3000).

Direct binding of lectins to the 2B8 antigens was tested with a twostep assay. First, 2B8 immunoprecipitates of unlabeled olfactory tissues were prepared and electrophoresed. Then, to visualize the antigens, individual gel lanes were incubated with ${ }^{125}$ I-labeled lectins or fresh $2 \mathrm{~B} 8 \mathrm{Mab}$ and ${ }^{125} \mathrm{I}$-protein A. Immunoprecipitation, electrophoresis, and preparation of gels for the gel-immunobinding procedure were done as previously described. RCA, Con A, and WGA were iodinated by the chloramine T method (Hunter and Greenwood, 1962). Lectins (1 to 5 $\mathrm{mg}$ at $10 \mathrm{mg} / \mathrm{ml}$ in PBS with $1.0 \mathrm{mM} \mathrm{CaCl}_{2}, 1.0 \mathrm{mM} \mathrm{MgCl}_{2}$, and 0.1 to $1.0 \mathrm{M}$ specific competing sugars) were added to $1.0 \mathrm{mCi}$ of carrier free $\mathrm{Na}^{125} \mathrm{I}$ (New England Nuclear) to a final volume of $1 \mathrm{ml}$. Chloramine $\mathrm{T}$ (Eastman) was added to $0.15 \mathrm{mg} / \mathrm{ml}$ for $5 \mathrm{~min}$. To stop the iodination, sodium metabisulfite (Fisher Scientific) was added to $0.18 \mathrm{mg} / \mathrm{ml}$ and the mixture was transferred to a $10-\mathrm{ml} \mathrm{Bio-Gel} \mathrm{P-10} \mathrm{(Bio-Rad)} \mathrm{column.}$ Fractions were eluted with hemoglobin containing buffer $(30 \mathrm{mg} / \mathrm{ml}$ of hemoglobin/PBS with $\mathrm{Ca}^{2+}, \mathrm{Mg}^{2+}$ ), collected in 1-ml aliquots, and counted. Fractions from the first radioactive peak were pooled and dialyzed against PBS with $\mathrm{Ca}^{2+}, \mathrm{Mg}^{2+}$. ${ }^{125}$ I-Lectin $\left(2\right.$ to $5 \times 10^{6} \mathrm{cpm} /$ $\mathrm{ml}$ in hemoglobin buffer; 1 to $10 \times 10^{8} \mathrm{cpm} / \mu \mathrm{g}$ ) was layered over gel lanes (about $800 \mu \mathrm{l} / \mathrm{lane}$ ) and incubated $8 \mathrm{hr}$ at room temperature. The gels were then washed for 3 days with multiple changes of $0.1 \%$ Triton $\mathrm{X}-100$ in iso-Tris, dried, and autoradiographed.

\section{Results}

Fusion and selection. Hybridoma cell lines were produced from the fusion of a mouse myeloma cell line (X63-Ag8.653non-Ig heavy/light chain producer) with spleen cells from a mouse immunized with PC12 cells. Antibodies which demonstrated immunoreactivity on nervous tissues but which in initial screens had a limited non-neural reactivity were investigated further. One Mab, designated 2B8, showed particularly high hinding to olfactory bulb and epithelium. Therefore, we chose to determine which olfactory cell types bind $2 \mathrm{~B} 8$.

The distribution of $2 B 8$ binding in neural tissues. Indirect immunofluorescence on rat olfactory bulb cryostat sections demonstrated 2B8 binding to the outer olfactory nerve layer and, with varying intensity, to individual olfactory glomeruli (Fig. 1, $b$ and $d$, arrows). Intense fluorescence was also seen on the glomerular layer of the accessory olfactory bulb (not shown). All other areas of the main olfactory bulb showed background levels (Fig. 1f) of $2 \mathrm{~B} 8 \mathrm{Mab}$ binding. The olfactory nerve layer and glomeruli contain, respectively, the axons and synaptic terminals of the primary olfactory receptor neurons of the olfactory epithelium. Therefore, immunofluorescence analyses of $2 \mathrm{~B} 8 \mathrm{Mab}$ binding to olfactory epithelium cryostat sections were performed. These showed dispersed throughout the epithelium prominent immunoreactive cells oriented perpendicular to the free surface (Fig. 2, b, c, and $f$ ). Many of these cells were bipolar, with apparent dendritic rods terminating in ciliated knobs at the surface of the epithelium and axons which extended through the basal lamina (Fig. 2c). These are the 

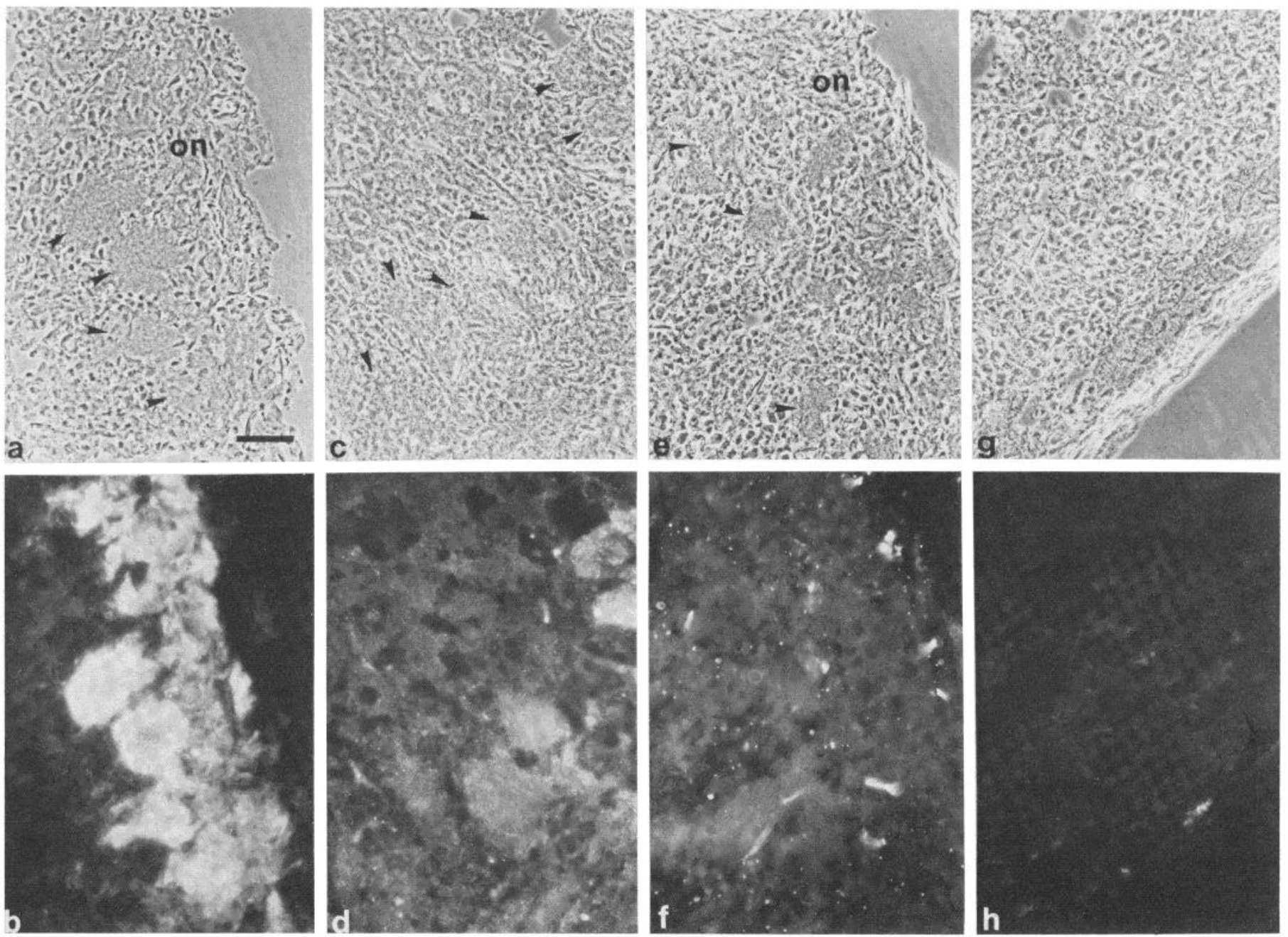

Figure 1. Immunofluorescence analysis of $2 \mathrm{~B} 8 \mathrm{Mab}$ binding to cryostat sections of 6-day neonatal rat olfactory bulb and cerebrum. Sections $(10 \mu \mathrm{m})$ were reacted with $2 \mathrm{~B} 8 \mathrm{Mab}(b$ and $d)$ or a Mab which does not bind rat tissues $\left(f ; 11-5.2 .1 .0\right.$; anti-mouse I-A ${ }^{\mathrm{k}}$ histocompatibility antigen; American Type Culture Collection) and then reacted with rhodamine-conjugated RxMIg. $a$ and $b$, Phase and fluorescence micrographs of dorsal medial area of bulb reacted with 2B8 Mab. Olfactory nerve layer (on) and glomeruli (arrowheads) are indicated. $c$ and $d$, Phase and fluorescence on another area of the olfactory bulb showing variability in 2B8 Mab binding. $e$ and $f$, Phase and fluorescence of an olfactory bulb section incubated with the nonreactive Mab. Slight nonspecific binding of second antibody is seen. $g$ and $h$, Phase and fluorescence on cerebrum reacted with $2 \mathrm{~B} 8 \mathrm{Mab}$. The calibration bar (a) is $50 \mu \mathrm{m}$ for all panels.

morphological characteristics of olfactory receptor neurons. In addition to the strong reactivity of cells with the morphology of receptor neurons, a subset of round cells in the presumptive basal cell layer of the olfactory epithelium showed moderate reactivity with the $2 \mathrm{~B} 8 \mathrm{Mab}$ (Fig. $2 f$ ). There were also patches of thin epithelium populated almost exclusively by tapered columnar cells which were 20 to $100 \%$ 2B8 positive (data not shown). The area below the basal lamina showed high levels of nonspecific binding with both 2B8 and control Mabs (Fig. 2, $b$, $e$, and $f$ ). $2 \mathrm{~B} 8$ also bound to many cells in the vomeronasal organ (VNO) (Fig. 2h). Multiple VNO cells and processes are tightly packed, and it is difficult to determine whether some of the cells do not bind $2 \mathrm{~B} 8$. Areas of respiratory epithelium ( $R E$, Fig. 2) were not above background fluorescence (Fig. 2i).

Other areas of the CNS and PNS including cerebrum, cerebellum, hippocampus, spinal cord, and DRG were examined by indirect immunofluorescence analyses on cryostat sections. All tissues except hippocampus showed background levels of binding (Fig. $1 h$ ). In hippocampus sections there was a diffuse band of very weak fluorescence in the molecular layer of the dentate gyrus (not shown). The significance of this weak fluorescence was not further pursued.
Radioimmunobinding analyses of $2 \mathrm{~B} 8 \mathrm{Mab}$ to particulate protein frcm CNS and PNS regions support the results obtained with immunofluorescence. Highest reactivity was found with the olfactory bulb and epithelium (Table I). Cerebrum, cerebellum, brainstem, and DRG showed detectable levels of binding, whereas the spinal cord, retina, superior cervical ganglion, and adrenal medulla were below background levels (see Footnote $a$ in Table I).

Analysis of $2 B 8 \mathrm{Mab}$ binding to non-neural tissues. Binding of $2 \mathrm{~B} 8 \mathrm{Mab}$ was not unique to neural tissues. Significant levels were found with adult rat intestine, salivary gland, and both rat and mouse testis in radioimmunoassays (Table I). Lower but significant binding was demonstrated in rat liver, lung, and bone marrow. Binding to bone marrow cannot be directly compared to other tissues since $2 \mathrm{~B} 8 \mathrm{~F}\left(\mathrm{ab}^{\prime}\right)_{2}$ fragments rather than IgGs were used. No other adult rat and mouse tissue assayed showed significant $2 \mathrm{~B} 8 \mathrm{Mab}$ binding.

Many cell surface antigens shared by the nervous and immune systems have been discovered (Reif and Allen, 1964; Akeson and Graham, 1981). Therefore, the cellular basis for $2 \mathrm{~B} 8$ binding in the immune system was examined. $2 \mathrm{~B} 8$ bound to about $25 \%$ of bone marrow cells in indirect immunofluores- 

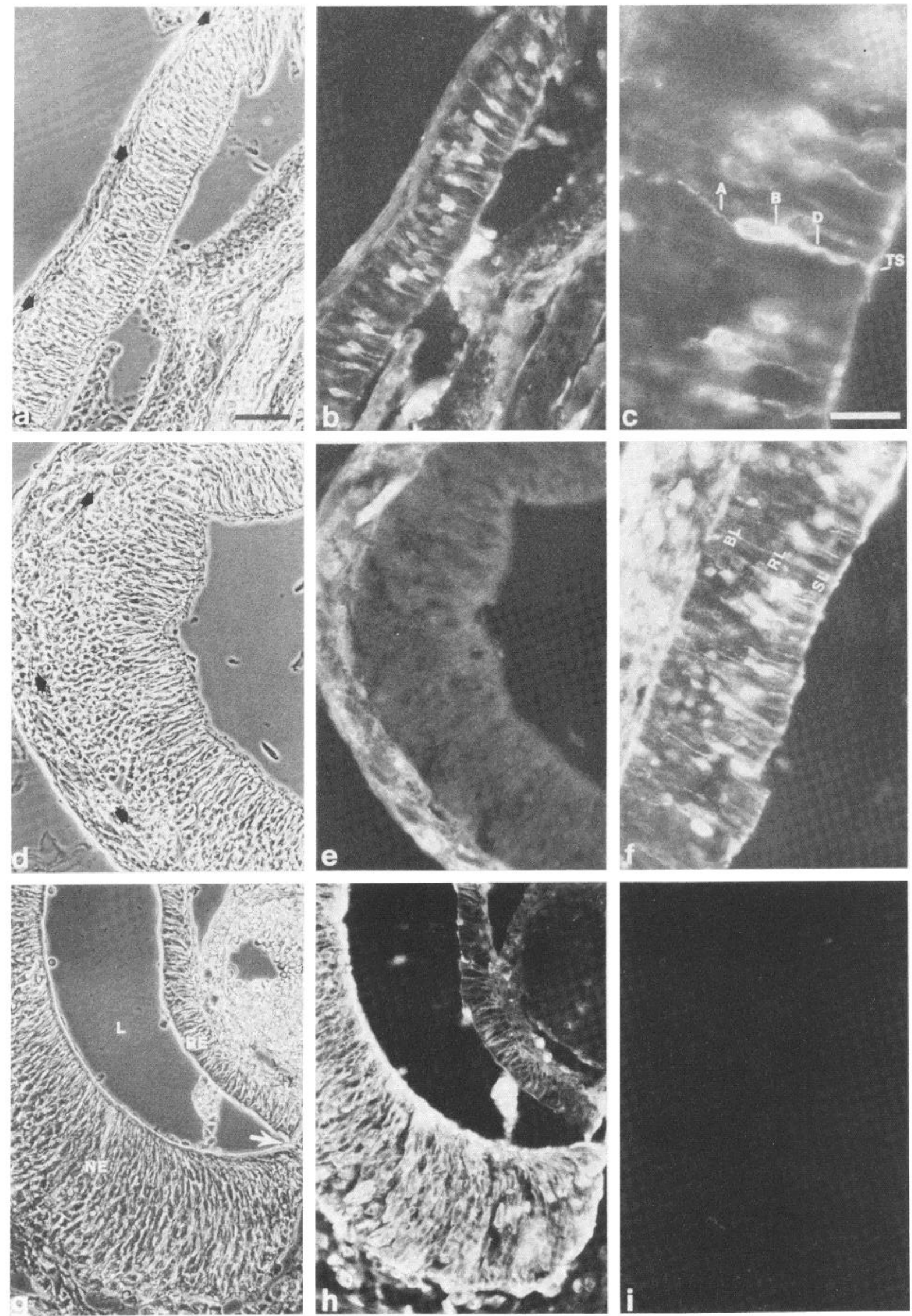

Figure 2 
TABLE I

Radioimmunobinding analysis of $2 B 8$ specific activity in adult rat tissues

$\begin{array}{ccc}\text { Adult Rat } & \text { Nanograms of } & \text { Standard Error of } \\ \text { TxMIg } & \text { Difference of } \\ \text { Tissue Homogenate } & \text { Bound } / 50 \mu \mathrm{g} & \text { Means }^{b}\end{array}$

Central Nervous Sys-

tem

Whole brain

Cerebrum

Cerebellum

Brainstem

Retina

Olfactory bulb

Olfactory epithelium

Spinal cord

$\begin{array}{rl}6.2 & 0.8 \\ 6.0 & 1.3 \\ 12.0 & 1.6 \\ 9.4 & 1.8 \\ 0.0 & 0.0 \\ 36.2 & 1.3 \\ 23.6 & 2.0 \\ 0.0 & 0.0\end{array}$

\section{Peripheral Nervous} System

Dorsal root ganglion

Superior cervical ganglion

Adrenal medulla

$\begin{array}{ll}4.5 & 1.8 \\ 0.0 & 0.0 \\ & \\ 0.0 & 0.0\end{array}$

Reproductive System

Ovary

Testis

Epididymal sperma-

0.0

52.7

21.8

0.0

1.8

tozoa

Hematopoietic System ${ }^{c}$

Bone marrow

Spleen

Thymus

\section{5}

0.0

0.0

0.0

25.3

0.0

4.3

3.7

38.0 lation(s) of non-mature $T$ lymphoid cells binds $2 B 8$ Mab. Identification of these bone marrow subsets has not been pursued.

Likewise, several cell surface antigens common to neural tissue and sperm have been found (Schachner, 1979; Fox et al., 1981). Therefore, $2 \mathrm{~B} 8$ binding to sperm was examined in greater detail. Radioimmunobinding analyses of spermatozoa taken from progressively more distal regions of the epididymus and vas deferens had moderately decreased 2B8 Mab binding (radioimmunobinding data not shown). Immunofluorescence staining of prefixed cells demonstrated total membrane fluorescence on greater than $90 \%$ of spermatozoa from testis and caput epididymus (Fig. 3b). Most spermatozoa from the corpus epididymus showed uniform fluorescence, but a consistent subpopulation of 10 to $15 \%$ had a mosaic pattern usually with bands of nonfluorescence in the neck region. In the caudal epididymus more than $90 \%$ of cells showed banding over the flagella with bright areas on the head (Fig. $3 d$ ). Spermatozoa from the vas deferens showed reduced fluorescence, usually with fluorescent bands only in the upper half of the tail and head regions (Fig. 3f). Immunofluorescence on testis cryostat sections showed 2B8 Mab binding to spermatozoa and to large round cells at the periphery of seminiferous tubules, presumed to be spermatogonia (data not shown). In summary, the 2B8 Mab binds spermatozoa and presumptive spermatogonia. Immunofluorescence localization of $2 \mathrm{~B} 8 \mathrm{Mab}$ binding on the spermatozoa cell surface demonstrates a mosaic pattern which changes during passage through the epididymus.

Effects of tissue preadsorption of $2 B 8 \mathrm{Mab}$ on tissue immunoreactivity. $2 \mathrm{~B} 8 \mathrm{Mab}$ binding to multiple tissues could be due to more than one reactive antibody produced by the hybridoma clone. This was tested by exhaustively preadsorbing the Mab ascites fluid with one reactive tissue and then assaying its ability to bind other reactive tissues using the radioimmunoassay described under "Materials and Methods." The preadsorption of $2 \mathrm{~B} 8$ ascites with olfactory bulb particulate protein (two times with $50 \mu \mathrm{g}$ of protein $/ \mu \mathrm{l}$ of ascites) removed all specific immunoreactivity to olfactory bulb, testis, bone marrow, salivary gland, and intestine particulate proteins. No significant binding could be detected in olfactory bulb and testis after preadorption of the $2 \mathrm{~B} 8 \mathrm{Mab}$ with testis particulate protein (two times with $50 \mu \mathrm{g}$ of protein $/ \mu \mathrm{l}$ of ascites). Preabsorption of $2 \mathrm{~B} 8$ ascites with bone marrow particulate protein (two times with $50 \mu \mathrm{g}$ of protein $/ \mu \mathrm{l}$ of ascites) removed all reactivity on olfactory bulb. Salivary gland membranes also removed specific 2B8 reactivity in olfactory bulb, intestine, and salivary gland (two times with $150 \mu \mathrm{g}$ of protein $/ \mu$ l of ascites). Exhaustive preadsorption with cerebellum particulate protein (two times with $375 \mu \mathrm{g}$ of protein $/ \mu$ l of ascites) did not reduce binding to olfactory bulb, salivary gland, or intestine. In summary, this assay indicates that the multiple tissues which react with the 2B8 Mab all react with the same population of immunoglobulin molecules.

Developmental changes in the binding of $2 B 8 \mathrm{Mab}$ in whole brain and liver. To understand the functional significance of the 2B8 antigen, the ontogenetic development of 2B8 Mab binding was examined in neural and non-neural tissue. Ra-

cence experiments. Consistent with the radioimmunobindi data, no 2B8-positive cells could be detected by immunofluorescence in thymus. These results suggest that a major popu-

Figure 2. Immunofluorescence analysis of $2 \mathrm{~B} 8 \mathrm{Mab}$ binding to cryostat sections of 6-day neonatal rat olfactory epithelium and VNO. Sections $(10 \mu \mathrm{m})$ were reacted with $2 \mathrm{~B} 8 \mathrm{Mab}$ ascites $(b, c, f$, and $h)$ or a Mab ascites which does not bind rat tissues (anti-mouse I-A ${ }^{\mathbf{k}}, e$ and $i$; see Fig. 1$)$ and then reacted with affinity-purified, rhodamine-conjugated RxMIg. $a$ and $b$, Phase and fluorescence micrographs of a medium-thick area of olfactory epithelium reacted with 2B8 Mab. Arrows in $\alpha$ and $d$ indicate the basal lamina. The calibration bar in $a$ is $50 \mu \mathrm{m}$ for all panels except $c$. $c$, Higher magnification of a putative olfactory receptor cell reacted with $2 \mathrm{~B} 8 \mathrm{Mab}$. The axon $(A)$, cell body $(B)$, dendrite $(D)$, and terminal swelling (TS) are indicated. The calibration bar represents $25 \mu \mathrm{m} . d$ and $e$, Phase and fluorescence micrographs of olfactory epithelium with negative control Mab. $f$, A thicker area of olfactory epithelium reacted with 2B8 Mab demonstrating fluorescent cell bodies in the basal cell layer $(B L)$ and receptor cell body layer $(R L)$ but not the supporting cell layer $(S L)$. $g$ and $h$. Phase and fluorescence micrographs of VNO reacted with 2B8 Mab. The arrow in $g$ indicates the boundary between neuroepithelium $(N E)$ and respiratory epithelium $(R E)$. The VNO lumen $(L)$ and a blood vessel $(B V)$ are also indicated. $i$, Fluorescence on VNO reacted with control anti-I-A $A^{\mathrm{k}}$. 

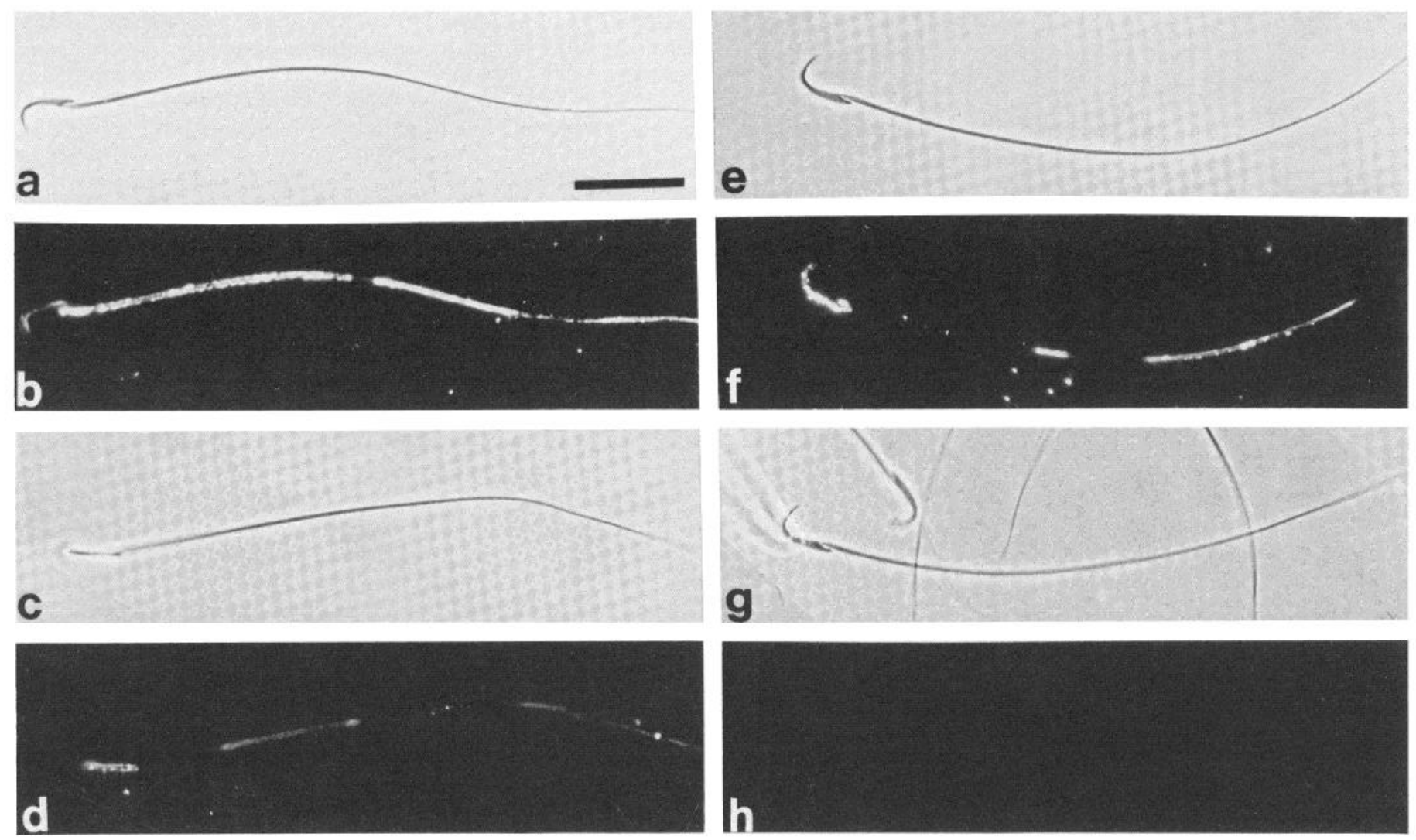

Figure 3. Immunofluorescence analysis of $2 \mathrm{~B} 8 \mathrm{Mab}$ binding to spermatozoa. Spermatozoa were isolated from the caput epididymus $(a, b, g$, and $h$ ), caudal epididymus ( $c$ and $d$ ), and vas deferens $(e$ and $f)$, immediately fixed, and then reacted with $2 \mathrm{~B} 8 \mathrm{Mab}$ ascites $(b, d$, and $f)$ or control anti-I-A ${ }^{\mathrm{k}}$ ascites $(h)$, followed by RxMIg. These were examined by phase $(a, c, e$, and $g)$ and fluorescence $(b, d, f$, and $h)$ optics.

dioimmunobinding analyses of $2 \mathrm{~B} 8 \mathrm{Mab}$ reactivity to whole brain demonstrated that significant binding appeared after birth, reaching adult levels in the early postnatal period (Fig. $4 a$ ). $2 \mathrm{~B} 8$ binding to the fetal body, excluding the head, reaches levels above background after embryonic day 15. A developmental curve of $2 \mathrm{~B} 8 \mathrm{Mab}$ reactivity in rat liver showed significant binding at birth dropping off to adult levels by postnatal day 10 (Fig. $4 b$ ). These results indicate that $2 \mathrm{~B} 8$ function in the liver is probably transient and may be related to the perinatal hematopoietic capabilities of that organ (Russell and Bernstein, 1966; Rifkind et al., 1969). In contrast, $2 B 8$ is present in both early postnatal and mature brain, suggesting a role for this antigen in both the developing and mature nervous system.

Binding of $2 \mathrm{~B} 8 \mathrm{Mab}$ by cell lines. The binding of the $2 \mathrm{~B} 8$ Mab to PC12 cell particulate protein (57.3 ng of RxMIg bound/ $50 \mu \mathrm{g}$ of particulate protein) was about double that seen in the olfactory system. Immunofluorescence on viable PC12 cells showed an even fluorescence over the total membrane surface. Induction of process outgrowth with nerve growth factor did not change the uniform distribution of binding (data not shown). None of the other cell lines tested by radioimmunoassay for 2B8 Mab reactivity - rat C6 glioma, B35 neuroblastoma, and B16 melanoma; mouse S91 melanoma and N18 neuroblastoma; hamster CCL49 melanoma; and the C6-N18 hybrid, NG108-had binding above background levels.

Molecular characterization of the $2 B 8$ antigens. To compare the 2B8 antigens across tissues and species, 2B8 binding to polypetides in SDS gels of unlabeled membrane proteins was examined ("Materials and Methods"). By this gel immunobinding method, the major PC12 2B8 antigens had $M_{\mathrm{r}}=43,000$ (possibly a doublet) and 51,000 (Fig. 5A, Table II). Within the resolution limits of the gel system, these bands appear to have molecular weights similar to those of bands obtained from immunoprecipitates of enzymatically iodinated and $\left[{ }^{3} \mathrm{H}\right]$ glucosamine or fucose biosynthetically labeled PC12 cells (data not shown).

Gel immunobinding analysis of membrane proteins from normal adult rat organs demonstrated $2 \mathrm{~B} 8$ binding proteins with a diversity of molecular weights among organs. Adult olfactory bulb and epithelium both had bands at $M_{\mathrm{r}}=215,000$ and 142,000. The 142,000-dalton band was also seen with PC12 (Fig. $5 A$ ). The VNO had four 2B8-reactive bands. Three VNO bands had molecular weights similar to those in olfactory bulb and epithelium, although they were much more diffuse. The bands of $M_{\mathrm{r}}=114,000$ and 69,000 were at higher levels in the VNO and were detectable in the olfactory bulb and epithelium only with longer exposure times. The greatest molecular weight band migrated slightly slower in the VNO $\left(M_{\mathrm{r}}=235,000\right)$ than in the olfactory bulb and epithelium $\left(M_{r}=215,000\right)$. DRG had a single immunoreactive band with $M_{\mathrm{r}}=114,000$. Spinal cord, which is negative for $2 \mathrm{~B} 8 \mathrm{Mab}$ reactivity by adsorption and immunofluorescence analyses, showed no specific immunoreactive bands by this gel immunobinding technique. Bone marrow and newborn liver each showed a single immunoreactive band at a molecular weight similar to that seen with DRG membranes, of 110,000 to 116,000 (Fig. $5 B$ ). Rat testis shared a band with PC12 at $M_{r}=42,000$ and had an additional band at $M_{r}=46,000$. Mouse testis also showed a band at $M_{\mathrm{r}}=46,000$ and one at 44,000 (data not shown). One more non-neural tissue was examined, salivary gland, which had bands of molecular weights similar to those of PC12 cells between 75,000 and 95,000 , a band at 114,000 similar to those of DRG, bone marrow, and newborn liver, and a unique band at 152,000 .

Glycoprotein nature of the olfactory $2 B 8$ antigens. The glycoprotein nature of the $2 \mathrm{~B} 8$ antigens in the olfactory system was 

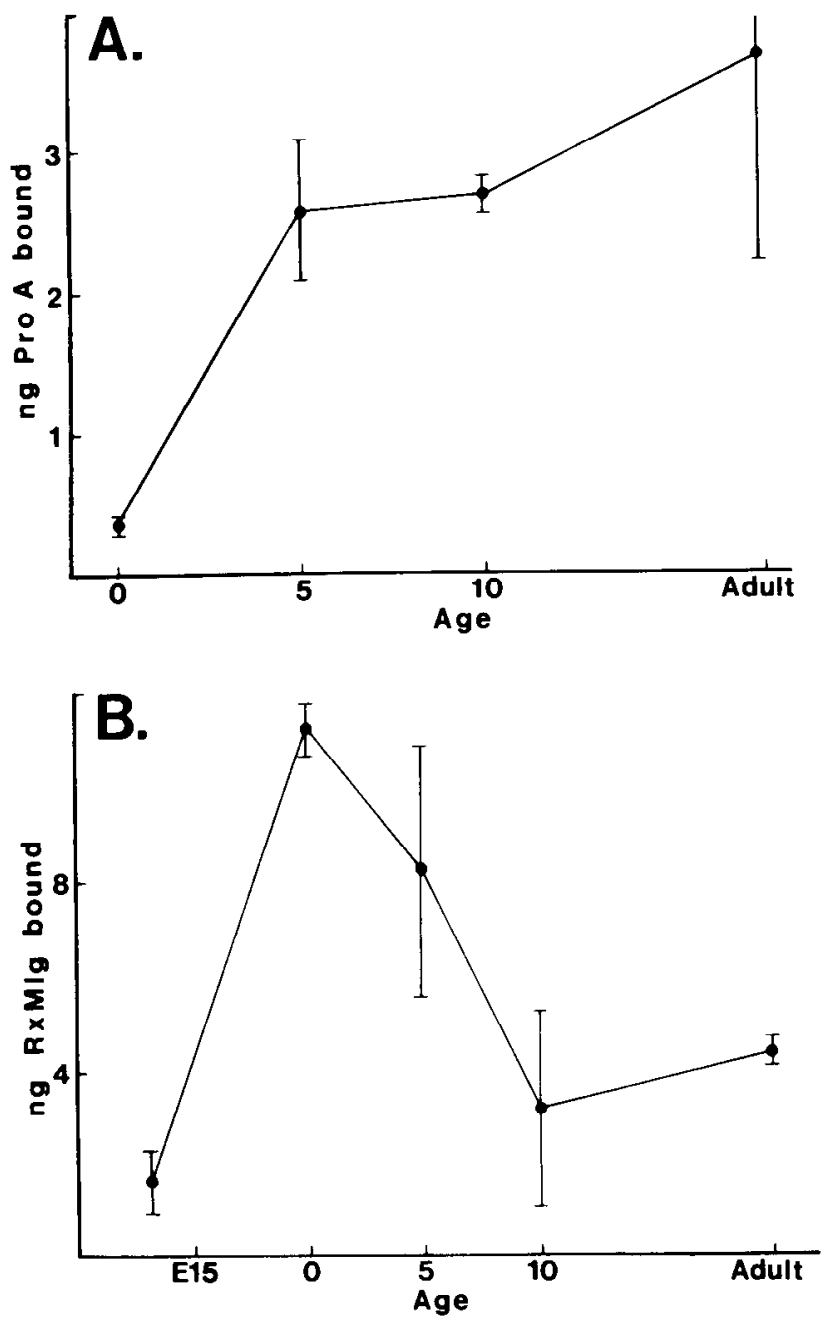

Figure 4. Radioimmunobinding analysis of 2B8 Mab in the developing rat brain and liver. For the analysis of binding to brain $(A)$, the iodinated second reagent used was ${ }^{125} \mathrm{I}$-protein A. For liver $(B),{ }^{125} \mathrm{I}$ rabbit-anti-mouse IgG was used. $F\left(a b^{\prime}\right)_{2}$ fragments of $2 B 8$ and cont rol Mabs rather than IgGs were used to assay liver to eliminate nonspecific $\mathrm{Fc}$ binding in perinatal samples. The particulate protein $(100 \mu \mathrm{g})$ was incubated with a predetermined excess of $2 \mathrm{~B} 8$ IgG or $\mathbf{F}\left(\mathrm{ab}^{\prime}\right)_{2}$ and washed, and then predetermined excess appropriate second reagent was added. The amount of second reagent bound is graphed as a function of age to illustrate 2B8 antigen specific activity during development.

demonstrated by lectin reactivity. $2 \mathrm{~B} 8$ immunoprecipitates of NP-40-solubilized olfactory bulb and epithelium particulate proteins were adsorbed with lectin-conjugated agarose beads. The unbound polypeptides in the bead supernatant were electrophoresed and analyzed for remaining $2 \mathrm{~B} 8$ immunoreactivity in a gel-immunobinding assay. WGA and RCA preadsorption lowered the intensity of the subsequent 2B8-immunoreactive bands of the olfactory bulb, whereas Con A, DBA, and SBA beads had little or no effect (Table III). In the presence of the specific monosaccharide inhibitor, D-galactose, RCA beads were not able to adsorb 2B8 reactivity. Likewise, $N$-acetylneuraminic acid and $N$-acetylglucosamine partially inhibited the ability of WGA heads to adsorb $2 \mathrm{~B} 8$ immunoreactivity.

Direct binding of ${ }^{125} \mathrm{I}$-lectins to $2 \mathrm{~B} 8$ antigens of the olfactory system was also shown. The band profile produced by the binding of ${ }^{125} \mathrm{I}$-WGA to electrophoresed unlabeled 2B8 immunoprecipitates of olfactory bulb (Fig. 6, lane a) looked very similar to that produced by gel immunobinding with $2 \mathrm{~B} 8 \mathrm{Mab}$, both having major bands at $M_{\mathrm{r}}=215,000$ and 142,000 (cf. Fig.
6 , lane $a$ with Fig. 5, lane $O B$ ). In the olfactory epithelium these two bands and an additional intense band $\left(M_{\mathrm{r}}=225,000\right)$ which migrated slightly slower than the 215,000 -dalton band were detected with ${ }^{125}$ I-WGA (Fig. 6, lane b). The olfactory epithelium immunoprecipitate developed with additional 2B8 Mab, and ${ }^{125}$ I-protein $A$ had the 215,000- and 142,000-dalton bands but did not show an intense 225,000-dalton band (Fig. 6, lane d). ${ }^{125}$ I-RCA produced results very similar to those for ${ }^{125} \mathrm{I}$ WGA, but Con A showed no specific binding to the 2B8 antigens (data not shown). Data from these two assays strongly suggest that the molecules recognized by the $2 \mathrm{~B} 8 \mathrm{Mab}$ in the olfactory system are glycoproteins with D-galactosyl and sialic acid or $N$-acetylglucosaminyl components.

In summary, immunoprecipitation, gel-immunobinding, and lectin-binding experiments indicate that $2 \mathrm{~B} 8 \mathrm{Mab}$ recognizes an antigenic site found on families of glycoproteins with diverse molecular weights. Some individual members of these families (as indicated by molecular weight) are found in multiple tissues, whereas others may be unique to individual tissues (Table II). Olfactory epithelium and bulb have a unique component at $M_{\mathrm{r}}$ $=215,000$, and the VNO has one at $M_{\mathrm{r}}=235,000$. The other olfactory $2 \mathrm{~B} 8$-reactive band at $M_{\mathrm{r}}=142,000$ was, by this single criterion of apparent molecular weight, shared with PC12 but not with any non-neural tissue.

\section{Discussion}

Mabs were produced from the immunization of mice with $\mathrm{PC} 12$, a neural crest-derived cell line having many characteristics of sympathetic neurons (Greene and Tischler, 1976). The 2B8 Mab, which showed specificity for neural tissues, was studied further. 2B8 Mab binding to PC12 cells and rat tissues was assayed by radioimmunobinding analyses. Highest reactivity was seen in testis and $\mathrm{PC} 12$ cell particulate proteins with greater than $50 \mathrm{ng}$ of RxMIg bound $/ 50 \mu \mathrm{g}$ of protein. Salivary gland, intestine, and olfactory bulb and epithelium also showed significant binding at 20 to $40 \mathrm{ng}$ of $\mathrm{RxMIg} / 50 \mu \mathrm{g}$ of protein. Other areas of the nervous system had lower specific activities. These results can be compared to the second assay, gel-immunobinding analyses of electrophoresed NP-40-solubilized particulate proteins. Olfactory bulb, bone marrow, and VNO had readily detectable $2 \mathrm{~B} 8$-reactive bands with short film exposure time. Newborn liver, PC12 cells, olfactory epithelium, and testis required somewhat longer exposure times (see the legend to Fig. 5). Also, a specific immunoreactive polypeptide could be detected in DRG but not cerebellum. Although this second method of antigen detection could allow the precise comparison of the relative specific activity of $2 \mathrm{~B} 8$ reactive polypeptides in different tissues, the data presented here cannot be used for quantitation since a number of gels were required and these were processed at several times with reagents of different specific activity. Therefore, only the rough comparisons above can be made. These are based on samples run within the same experiment. A third assay which reflects the relative reactivity of different rat tissues is tissue cross-absorption. An equal amount $(100 \mu \mathrm{g})$ of olfactory bulb, testis, or bone marrow particulate protein was able to completely remove all activity from $1.0 \mu \mathrm{l}$ of $2 \mathrm{~B} 8$ ascites fluid, whereas 3 times the amount (300 $\mu \mathrm{g}$ of particulate protein) of salivary gland was required to remove all reactivity. After extensive absorption with cerebellum particulate protein (750 $\mu \mathrm{g}$ of protein $/ \mu \mathrm{l}$ of ascites), there was no reduction in 2B8 Mab immunoreactivity to olfactory bulb, salivary gland, or intestine. Combined, these three assays indicate the following. (1) The adult rat tissues showing the greatest 2B8 Mab immunoreactivity are olfactory bulb, olfactory epithelium, testis, and bone marrow. Salivary gland and intestine are either the same or slightly less reactive than these four. (2) If the olfactory epithelium and VNO are assayed separately by radioimmunobinding or gel immunobinding, the 
TABLE II

Apparent molecular weights of 2B8-immunoreactive bands recognized in rat tissues and PC12 cells

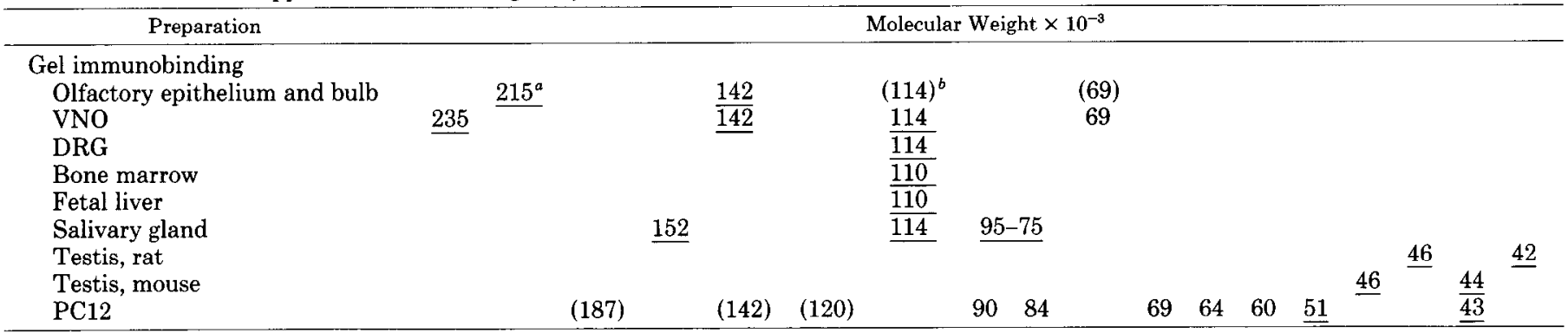

${ }^{a}$ All major bands are underlined.

${ }^{b}$ All minor bands detectable with longer times are in parentheses.

\section{TABLE III}

Lectin bead adsorption of $2 B 8$ immunoprecipitates

2B8 immunoprecipitates of olfactory bulb were adsorbed with lectinconjugated agarose beads. The beads were removed by centrifugation and the supernatants containing unbound proteins were electrophoresed on an $8 \%$ polyacrylamide gel. The 2B8-reactive bands were detected by the gel-radioimmunobinding procedure and the two major 2B8-immunoreactive bands were scanned with a spectrodensitometer (see "Materials and Methods").

\begin{tabular}{lcc}
\hline \multirow{2}{*}{ Lectin } & \multicolumn{2}{c}{$\begin{array}{c}\text { 2B8 Binding Remaining } \\
\text { (\% of control) }\end{array}$} \\
\cline { 2 - 3 } & $M_{\mathrm{r}}=215,000$ & $M_{\mathrm{r}}=142,000$ \\
\hline Con A & 103 & 109 \\
DBA & 82 & 94 \\
$\mathrm{RCA}^{b}$ & $36^{c}$ & $39^{c}$ \\
$\mathrm{SBA}^{c}$ & 103 & 102 \\
WGA $^{d}$ & $38^{c}$ & $46^{c}$ \\
\hline
\end{tabular}

${ }^{a}$ The control $2 \mathrm{~B} 8$ immunoprecipitate was adsorbed with unconjugated Bio-Gel A-5m agarose beads. Nonspecific binding (anti-IA ${ }^{k}$ immunoprecipitate, unabsorbed, analyzed by the same procedure) was subtracted from each adsorbed sample; then the percentage of each 2B8 band remaining (lectin bead adsorbed per A-5 bead adsorbed) was calculated.

${ }^{b}$ RCA adsorption of 2 B8 immunoreactivity was completely inhibited in the presence of $1.0 \mathrm{M} \mathrm{D}$-galactose.

${ }^{c} 2 \mathrm{~B} 8$ immunoreactivity was lowered significantly but not completely. The use of increasing amounts of lectin beads to determine saturation points was not performed.

${ }^{d}$ WGA bead adsorption of $2 \mathrm{~B} 8$ immunoreactivity was partially reduced in the presence of $0.1 \mathrm{M} \mathrm{N}$-acetylneuraminic acid and $N$-acetylglucosamine.

greater reactivity is seen in the VNO. This has been confirmed by immunofluorescence analyses of olfactory bulb and epithelium which show very intense 2B8 Mab binding to the VNO and the glomerular layer of the accessory olfactory bulb, which contains the synaptic termini of chemosensory neurons of the VNO. (3) Some non-olfactory areas of the CNS such as cerebellum demonstrated detectable $2 \mathrm{~B} 8$ binding by the radioimmunobinding assay. However, the cerebellum had no specific
2B8 binding in immunofluorescence experiments with both fixed and unfixed tissues. It also did not have detectable specific 2B8 immunoreactivity in the antibody adsorption and gel immunobinding protocols. These three assays suggest that the low levels of $2 \mathrm{~B} 8$ binding observed with cerebellum in the radioimmunobinding assay may be due to $2 \mathrm{~B} 8 \mathrm{Mab}$-nonspecific binding not seen in the control.

Other studies have demonstrated a cross-reactivity of antibodies to the nervous, hematopoietic, and reproductive systems (Reif and Allen, 1964; Schachner, 1979; Akeson and Graham, 1981; Fox et al., 1981; Granger and Lazarides, 1983). Therefore, the cross-reactivity seen with the $2 \mathrm{~B} 8 \mathrm{Mab}$ is not unexpected. The critical question is whether the antigen molecules are completely identical or distinct, but with a common antigenic determinant(s) (Lane and Koprowski, 1982; Haspel et al., 1983).

To characterize the 2B8 antigen(s) expressed in different tissues, NP-40-solubilized particulate proteins were electrophoresed and then the gels were analyzed for 2B8-reactive bands by radioimmunobinding. 'Ihis method is similar to immunoblotting, in which the electrophoresed polypeptides are first transferred to nitrocellulose sheets followed by immunological procedures of detection (Towbin et al., 1979). Although the immunoblot procedure takes much less time, the transfers are often not quantitative due to variability in both the rate of transfer of polypeptides of different molecular weights and the nitrocellulose binding of the polypeptides. Therefore, the method used here gives more reliable results in this system. We have shown that the $2 \mathrm{~B} 8 \mathrm{Mab}$ recognizes a single polypeptide with $M_{\mathrm{r}}=110,000$ to 114,000 in three distinct tissues: bone marrow, newborn liver, and DRG. A band of similar molecular weight is also seen in the VNO, salivary gland, and at low levels in olfactory bulb and epithelium. This $110,000-$ to $114,000-$ dalton antigen may be expressed by a particular cell type found in each of these systems. Alternatively, an identical antigen with a common function may be expressed by different cell types. The olfactory system also has at least three additional 2B8-immunoreactive bands: one unique to the olfactory bulb and epithelium at $M_{\mathrm{r}}=215,000$, one unique to the VNO at $M_{r}$

Figure 5. 2B8 Mab binding to electrophoresed solubilized membranes of neural and non-neural rat tissues and PC12 cells. Tissue particulate proteins solubilized in Laemmli sample buffer were electrophoresed on $8 \%$ SDS-polyacrylamide gels (salivary gland proteins were separated on a $10 \%$ gel) at $100 \mu \mathrm{g} /$ lane except for VNO which was $50 \mu \mathrm{g} /$ lane. The gels were reacted with $2 \mathrm{~B} 8 \mathrm{Mab}(+)$ control or anti-I-A $\mathrm{kab}$ ascites $(-)$ and then with ${ }^{125}$ I-protein A as described under "Materials and Methods." The lanes were autoradiographed for different lengths of time to equalize the band intensities. 'This figure is a composite of several experiments which used ${ }^{125} 1$-protein A preparations of varying specific activities. $A$, The neural tissues examined included olfactory epithelium $(O E$, autoradiography film was exposed to labeled gel for $8 \mathrm{hr})$, olfactory bulb ( $O B$, exposed for $30 \mathrm{~min}$ ), VNO (exposed for $3 \mathrm{hr}$ ), DRG (exposed for $36 \mathrm{hr}$ ), and spinal cord (SC, a negative tissue control; exposed for $36 \mathrm{hr}$ ). PC12 lanes were autoradiographed for $8 \mathrm{hr}$ in $A$ and $16 \mathrm{hr}$ in $B$. $B$, The non-neural tissues examined included bone marrow (BM, exposed for $30 \mathrm{~min}$ ), newborn liver ( $L I V$, exposed for $5 \mathrm{hr}$ ), testis ( $T$, exposed for $28 \mathrm{hr}$ ), and salivary gland ( $S G$, exposed for $12 \mathrm{hr}$ ). Analysis was performed on eight or more preparations of each olfactory tissue and two or more preparations of each non-olfactory tissue. The molecular weight markers used were ${ }^{14} \mathrm{C}$-macroglobulin ( 185,000 daltons), ${ }^{14} \mathrm{C}$-bovine serum albumin $\left(69,000\right.$ daltons), and ${ }^{14} \mathrm{C}$-ovalbumin (46,000 daltons; all from New England Nuclear). 


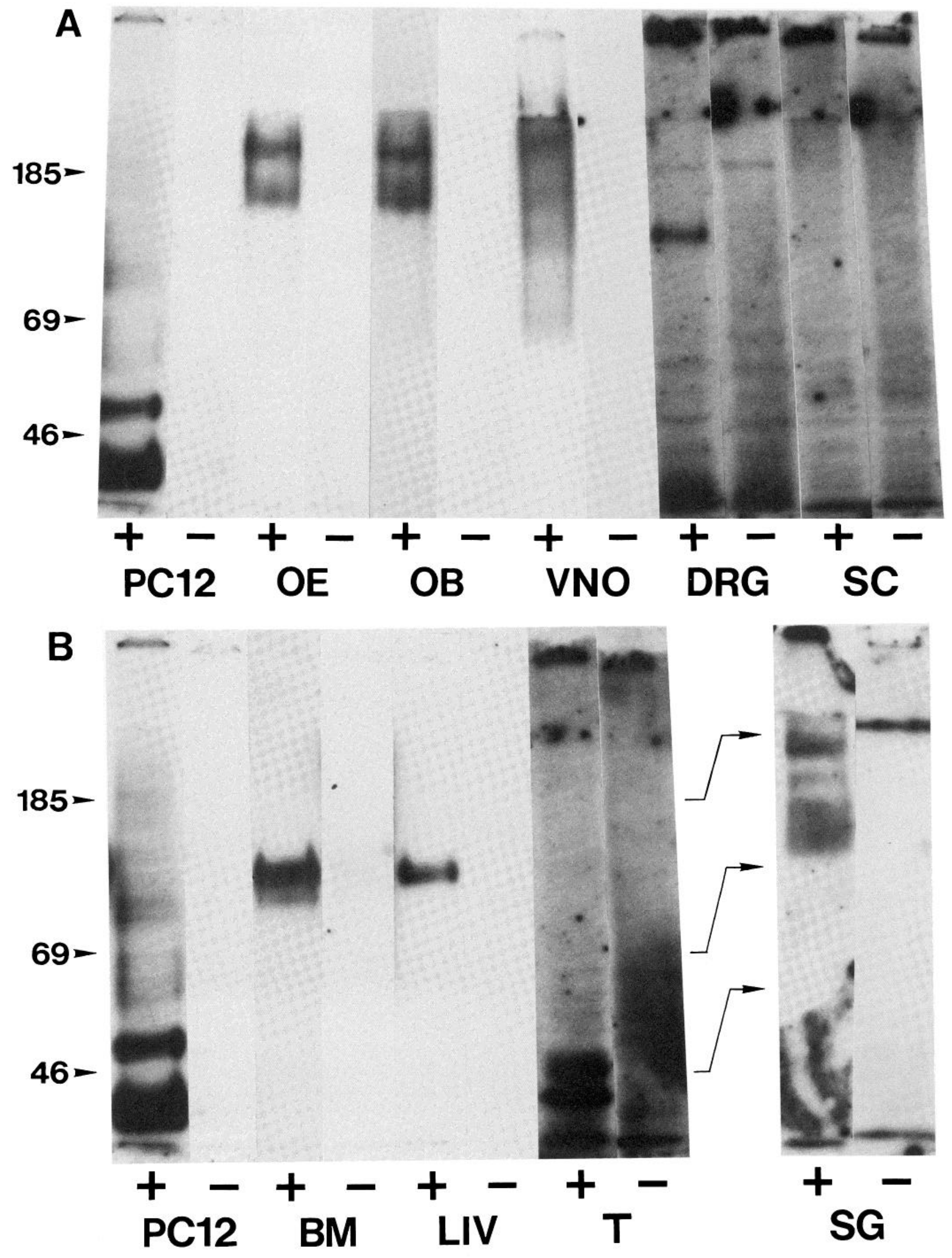




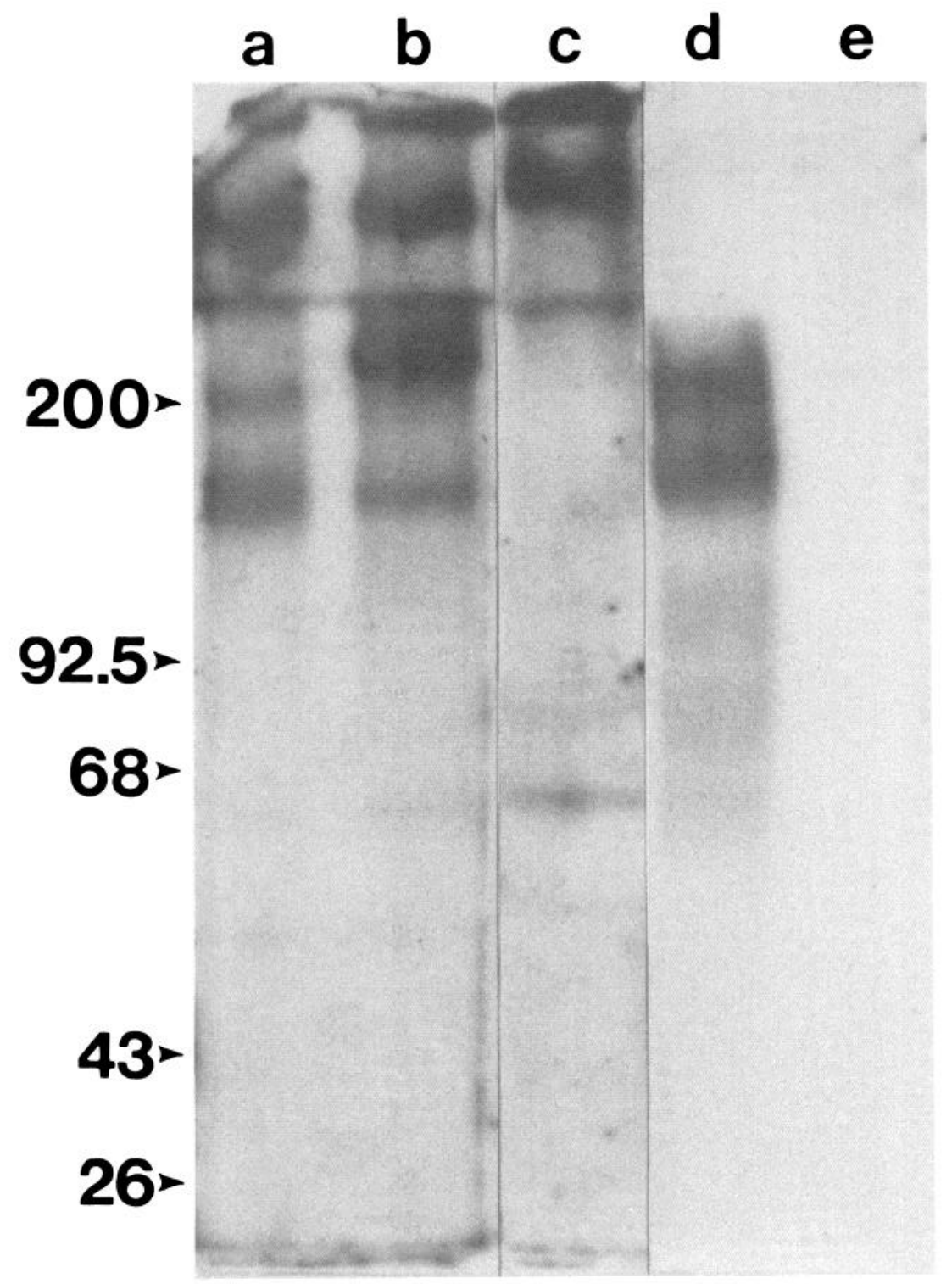

Figure 6. ${ }^{125} \mathrm{I}-\mathrm{WGA}$ binding to $2 \mathrm{~B} 8$ immunoprecipitates of adult olfactory tissues. 2B8 (lanes $a, b$, and $d$ ) and anti-I-A $A^{k}$ (lanes $c$ and $e$ ) Mab immunoprecipitates of unlabeled olfactory tissues were prepared and electrophoresed as for the gel-immunobinding procedure. The gel lanes were then reacted with ${ }^{125}$ I-WGA (lanes $a$ to $c$ ) or with fresh 2B8 Mab and ${ }^{125} \mathrm{I}$-protein $\mathrm{A}$ (lanes $d$ and $e$ ). $a, 2 \mathrm{~B} 8$ immunoprecipitate of olfactory bulb reacted with ${ }^{125}$ I-WGA. $b, 2 \mathrm{~B} 8$ immunoprecipitate of olfactory epithelium reacted with ${ }^{125}$ I-WGA. $c$, Anti-I-A ${ }^{k}$ Mab immunoprecipitate of olfactory epithelium reacted with ${ }^{125} \mathrm{I}$ WGA. $d, 2 \mathrm{~B} 8$ immunoprecipitate of olfactory epithelium reacted with $2 \mathrm{~B} 8 \mathrm{Mab}$ and ${ }^{125} \mathrm{I}$-protein A. $e$, Anti-I-A $\mathrm{A}^{\mathrm{k}}$ Mab immunoprecipitate of olfactory epithelium reacted with $2 \mathrm{~B} 8 \mathrm{Mab}$ and ${ }^{125} \mathrm{I}$-protein A.

235,000 , and one at a molecular weight seen only in the olfactory system and PC12 cells $\left(M_{\mathrm{r}}=142,000\right)$. Multiple band patterns of each tissue obtained using the gel-immunobinding procedure could be due to (1) products of partial proteolysis or processing of the cell surface antigen, (2) similar or identical polypeptides with different post-translational modifications, or (3) independent gene products with similar or identical antigenic determinants. In order to reduce the effects of proteolysis following tissue isolation, protease inhibitors were added during homogenization and membrane solubilization. Samples were handled quickly and held on ice except during immunoreactive steps. An NP-40-solubilized olfactory epithelium particulate protein preparation incubated at room temperature for $11 \mathrm{hr}$ prior to electrophoresis and gel immunobinding had an identical pattern of immunoreactive bands, suggesting that autodigestion was not a problem. The other more interesting possibilities which might explain the multiple $2 \mathrm{~B} 8$ antigens are being investigated. In returning to the original question of whether the 2B8 Mab is recognizing identical or dissimilar molecules in cross-reactive tissues, by the single criterion of electrophoretic mobility, it is suggested that the $2 \mathrm{~B} 8 \mathrm{Mab}$ binds to a family of diverse molecules, some shared by and some unique to individual tissues.

In the olfactory system the glycoprotein nature of the $2 \mathrm{~B} 8$ antigens was demonstrated by adsorbing olfactory bulb $2 \mathrm{~B} 8$ immunoprecipitates with a number of lectin-conjugated agarose beads. WGA and RCA significantly lowered the intensity of the $2 \mathrm{~B} 8$-immunoreactive bands. In the presence of D-galactose, RCA was unable to remove reactivity from the $2 \mathrm{~B} 8$ immunoprecipitate. Sialic acid reduced WGA bead adsorption by a small amount. Saturation conditions for lectin bead adsorptions and sugar competition were not predetermined; therefore, complete adsorption of $2 \mathrm{~B} 8$ immunoreactivity by RCA and WGA beads and a greater WGA blocking effect by the specific sugar may be achieved using optimal concentrations. Alternatively, the immunoreactivity remaining may represent a specifically glycosylated subpopulation within a single $2 \mathrm{~B} 8$-reactive band.

Direct binding of iodinated lectins to electrophoresed 2B8 antigens also demonstrated reactivity with RCA and WGA but not Con A. The additional lectin-reactive band seen in the olfactory epithelium immunoprecipitate was probably a minor subpopulation of the 215,000-dalton band since it was not particularly evident by $2 \mathrm{~B} 8$ gel immunobinding. The detection of this band in the epithelium but not the bulb raises the possibility this antigen may be expressed by cells other than mature olfactory receptor neurons. Alternative hypotheses including processing of this band during axonal transport are also consistent with the available data. The glycoprotein nature of 
the 2B8 antigens has also been shown in PC12 cells. The electrophoretic profiles of immunoprecipitates from lactoperoxidase-iodinated PC12 cells and $\left[{ }^{3} \mathrm{H}\right]$ glucosamine or fucose biosynthetically labeled cells were very similar.

olfactory receptor cells, the chemosensory neurons in the olfactory system, are located in the olfactory epithelium which lines the nasal septum and turbinates. The olfactory epithelium is made up of three basic cell types-the receptor, basal, and supporting cells (Moulton and Beidler; 1967; Graziadei and Monti Graziadei, 1978). In the olfactory system, no other receptor cell surface components have been described previously, although internal "markers" have been proposed. A 16,500 -dalton acidic cytoplasmic protein specific to olfactory receptor cells has been isolated (Keller and Margolis, 1975). Immunohistochemical localization of this olfactory marker protein (OMP) demonstrates staining of mature receptor cells of the olfactory epithelium and VNO. The VNO has very low levels until postnatal day 4. Anti-OMP staining was found in receptor cell bodies, dendrites, and axons (Farbman and Margolis, 1980; Monti Graziadei et al., 1980). These and other studies have clearly established OMP as a unique constituent of mature olfactory receptor neurons. Two other putative markers for receptor cells are carnosine and carnosine synthetase, which are found at higher levels in the olfactory bulb and epithelium than in any other brain region (Margolis, 1974; Neidle and Kandera, 1974). Carnosine, believed to be a neurotransmitter in the primary olfactory pathway, is found at high levels in receptor neurons co-distributed with its anabolic enzyme carnosine synthetase (Burd et al., 1982).

2B8 Mab binds to cell surface components of olfactory receptors and also presumptive basal cells and VNO cells. Regions of the olfactory epithelium differ in thickness, possibly reflecting different stages of normal olfactory turnover. Areas of very thick epithelium show many 2B8-positive cells, but their binding intensity is lower than that of 2B8-binding cells found dispersed throughout medium-thick areas. Some epithelial areas containing presumptive basal cells show moderate 2B8 Mab binding. The Mab also recognizes a class of olfactory epithelial cells of columnar or tapered morphology found as a single cell layer over the basal lamina. Immunofluorescence analyses of these areas show variability in percentage of cells with 2B8 immunoreactivity. Patches of four or more 2B8positive cells are often observed periodically dispersed among the 2B8-negative cells. No morphological differences between them can be observed by phase microscopy. In the olfactory epithelium the 2B8 Mab does not appear to bind to all cells of olfactory receptor cell morphology or to a large percentage of cells in the basal cell layer. However, in the VNO, a high proportion of the cells are $2 \mathrm{~B} 8$ immunoreactive. Because of the intensity of VNO fluorescence it is difficult to discern reactive from nonreactive cells when they are closely apposed. In the olfactory bulb only those areas containing receptor cell axons, including the olfactory nerve and glomerular layers, showed $2 \mathrm{~B} 8$ binding. Certain areas of the glomerular layer show more intense fluorescence than other areas. This variable binding to glomeruli was also seen in cryostat sections of 26-day and adult rat olfactory bulbs. These data all suggest that the 2B8 Mab may recognize a subset of receptor neurons. This subset may be one of the following. (1) Odor-processing group. In initial experiments the 2B8-positive receptor cells appear to synapse predominantly in glomeruli located in dorsal medial areas of the 6-day olfactory bulb since these areas show the grealest $2 \mathrm{~B} 8 \mathrm{Mab}$ reactivity. Localized excitation in the glomerular layer of the olfactory bulb in response to odors has been described using the 2-deoxyglucose technique. Distinct glomerular patterns of excitation are caused by particular odors (Moulton, 1976; Sharp et al., 1977; Stewart et al., 1979; Jourdan et al., 1980; Greer et al., 1982). The pattern of binding by the $2 \mathrm{~B} 8$ Mab to the olfactory bulb glomeruli may reflect such a func- tional group of receptors. (2) Age class. As mentioned earlier, the differences in olfactory epithelium thickness may reflect turnover activity. $2 \mathrm{~B} 8$ binding is most intense on cells found in thin and medium-thick areas of the olfactory epithelium. Cells in thick regions show less binding. OMP appears to be a stage-specific marker as it is present only in mature receptors (Farbman and Margolis, 1980; Monti Graziadei et al., 1980). 2B8 antigen can be detected on a few bipolar cells with the morphology of receptor neurons in the olfactory epithelium at embryonic day 13.5. This is about 4 days before the receptor cell axons innervate the olfactory bulb. Therefore, the 2B8 antigen appears to be expressed by cells at multiple stages of development. (3) Receptor neuron morphologic subclass. The existence of morphological subtypes of receptor cells has been suggested in a number of studies (for review of literature, see Moulton and Beidler, 1967). For example, Moran et al. (1982) described a microvillous olfactory receptor cell type in human nasal mucosa. These may be similar to microvillous receptor neurons believed to be the major receptor cell type in the VNO in other mammals. The distribution of the microvillar cells in rats may be similar to that of the cells recognized by the $2 \mathrm{~B} 8$ Mab. This morphological classification may also be a functional one. Thommeson (1983) has found in salmonid fish two types of receptor cells ciliated and microvillar which are distrib uted differentially in the olfactory epithelium. It is suggested that the ciliated receptor cells are activated by bile salts whereas the microvillar receptor cells are activated by amino acids. To test more rigorously the hypothesis that receptor neurons expressing the 2B8 antigens are a subset of all receptor cells, an immunofluorescence analysis of olfactory epithelium by double label with 2B8 Mab and anti-OMP antisera would be useful.

In summary, the 2B8 Mab defines the first cell surface marker on olfactory receptor neurons. Although the Mab crossreacts with other rat tissues, the molecular weights of the antigens recognized are not identical but are a diverse family of glycoproteins of both shared and unique molecular weight classes. One of the olfactory antigens recognized has a molecular weight similar to that of a $2 \mathrm{~B} 8$ antigen in $\mathrm{PC} 12$ cells and the other is unique to the olfactory system.

\section{References}

Akeson, R. (1979) Cell surface antigens of cultured neuronal cells. Curr Top. Dev. Biol. 13: 215-236.

Akeson, R., and K. L. Graham (1981) A new antigen common to the rat nervous and immune systems. I. Detection with a hybridoma. J. Neurosci. Res. 6: 165-177.

Akeson, R., and W-C. Hsu (1978) Identification of a high molecular weight nervous system specific cell surface glycoprotein on murine neuroblastoma cells. Exp. Cell Res. 115: 367-377.

Akeson, R., and S. L. Warren (1982) A cell surface antigen of the developing neuronal process. J. Cell Biol. 95: 104a.

Allen, W. K., and R. Akeson (1983) A monclonal antibody detects a cell surface glycoprotein family found on olfactory receptor neurons. Soc. Neurosci. Abstr. 9: 1019

Banker, G. A., and W. M. Cowan (1977) Rat hippocampal neurons in dispersed cell culture. Brain Res. 126:397-425.

Barnstable, C. J. (1980) Monoclonal antibodies which recognize differ ent cell types in the rat retina. Nature 286:231-235.

Bock, E., Z. Yavin, O. S. Jørgensen, and E. Yavin (1980) Nervous system-specific proteins in developing rat cerebral cells in culture. J. Neurochem. 35: 1297-1302.

Brackenbury, R., J. -P. Thiery, U. Rutishauser, and G. M. Edelman (1977) Adhesion among neural cells of the chick embryo. I. An immunological assay for molecules involved in cell-cell binding. J. Biol. Chem. 252: 6835-6840.

Burd, G. D., B. J. Davis, F. Macrides, M. Grillo, and F. L. Margolis (1982) Carnosine in primary afferents of the olfactory system: An autoradiographic and biochemical study. J. Neurosci. 2: 244-255.

Burridge, K. (1976) Changes in cellular glycoproteins after transformation: Identification of specific glycoproteins and antigens in so- 
dium dodecyl sulfate gels. Proc. Natl. Acad. Sci. U. S. A. 73: $4457-$ 4461.

Cohen, J., and S. Y. Selvendran (1981) A neuronal cell-surface antigen is found in the CNS but not in peripheral neurons. Nature 291:421423.

Farbman, A. I., and F. L. Margolis (1980) Olfactory marker protein during ontogeny: Immunohistochemical localization. Dev. Biol. 74 205-215.

Fox, N., I. Damjanov, A. Martinez-Hernandez, B. B. Knowles, and D. Solter (1981) Immunohistochemical localization of the early embryonic antigen (SSEA-1) in postimplantation mouse embryos and fetal and adult tissues. Dev. Biol. 83: 391-398.

Freeman, W. M. (1974) Topographic organization of primary olfactory nerve in cat and rabbit as shown by evoked potentials. Electroencephalogr. Clin. Neurophysiol. 36: 33-45.

Galfre, G., S. C. Howe, C. Milstein, G. W. Butcher, and J. C. Howard (1977) Antibodies to major histocompatibility antigens produced by hybrid cell lines. Nature 266: 550-552.

Granger, B. L., and E. Lazarides (1983) Expression of the major neurofilament subunit in chicken erythrocytes. Science 221: 553556.

Graziadei, P. P. C., and G. A. Monti Graziadei (1978) Continuous nerve cell renewal in the olfactory system. In Handbook of Sensory Physiology. Vol. 9: Development of Sensory Systems, M. Jacobson, ed., pp. 55-83, Springer-Verlag, Berlin.

Greene, L. A., and A. S. Tischler (1976) Establishment of a noradrenergic clonal line of rat adrenal pheochromocytoma cells which respond to nerve growth factor. Proc. Natl. Acad. Sci. U. S. A. 73: 2424-2428.

Greer, C. A., W. B. Stewart, J. S. Kauer, and G. M. Shepherd (1981) Topographical and laminar localization of 2-deoxyglucose uptake in rat olfactory bulb induced by electrical stimulation of olfactory nerves. Brain Res. 217: 279-293.

Haspel, M. V., T. Onodera, B. S. Prabhaker, P. R. McClintock, K. Essani, U. R. Ray, S. Yagihashi, and A. L. Notkins (1983) Multiple organ-reactive monoclonal autoantibodies. Nature 304: 73-76.

Hempstead, J. L., and J. I. Morgan (1983) Monoclonal antibodies to the rat olfactory sustentacular cell. Brain Res. 288: 289-295.

Hunter, W. M., and F. C. Greenwood (1962) Preparation of iodine-131 labelled human growth hormone of high specific activity. Nature 1.94: 495-496.

Jourdan, F., A. Duveau, L. Astic, and A. Holley (1980) Spatial distribution of $\left[{ }^{14} \mathrm{C}\right] 2$ deoxyglucose uptake in the olfactory bulbs of rats stimulated with two different odours. Brain Res. 188: 139-154.

Keller, A., and F. L. Margolis (1975) Immunological studies of the rat olfactory marker protein. J. Neurochem. 24: 1101-1106.

Laemmli, U. K. (1970) Cleavage of structural proteins during the assembly of the head of bacteriophage T4. Nature 227: 680-685.

Lane, D., and H. Koprowski (1982) Molecular recognition and the future of monoclonal antibodies. Nature 296: 200-202.

Langley, O. K., M. S. Ghandour, G. Gombos, M. Hirn, and C. Goridis (1982) Monoclonal antibodies as neural cell surface markers. Neurochem. Res. 7: 349-362.

Lowry, O. II., N. J. Rosebrough, A. L. Farr, and R. J. Randall (1951) Protein measurement with the Folin phenol reagent. J. Biol. Chem. 193: 265-275.

Margolis, F. L. (1974) Carnosine in the primary olfactory pathway. Science 184: 909-911.

McKay, R. D. G., and S. J. Hockfield (1982) Monoclonal antibodies distinguish antigenically discrete neuronal types in the vertebrate central nervous system. Proc. Natl. Acad. Sci. U. S. A. 79: 67476751.

Monti Graziadei, G. A., R. S. Stanley, and P. P. C. Graziadei (1980) The olfactory marker protein in the olfactory system of the mouse during development. Neuroscience 5: 1239-1252.

Moran, D. T., J. C. Rowley, III, B. W. Jafek, and M. A. Lovell (1982) The fine structure of the olfactory mucosa in man. J. Neurocytol. 11: $721-746$.

Moulton, D. G. (1976) Spatial patterning of response to odors in the peripheral olfactory system. Curr. Top. Physiol. 56: 578-593.

Moulton, D. G., and L. M. Beidler (1967) Structure and function in the peripheral olfactory system. Physiol. Rev. 47: 1-52.

Moulton, D. G., G. Celebi, and R. P. Fink (1970) Olfaction in mammals - two aspects: Proliferation of cells in the olfactory epithelium and sensitivity to odours. In Taste and Smell in Vertebrates: A Ciba Foundation Symposium, G. E. W. Wolstenholme and J. Knight, eds., pp. 227-246, Churchill, London.

Neidle, A., and J. Kandera (1974) Carnosine--an olfactory bulb peptide. Brain Res. 80: 359-364.

Reif, A. E., and J. M. V. Allen (1964) The AKR thymic antigen and its distribution in leukemias and nervous tissues. J. Exp. Med. 120:413433.

Rifkind, R. A., D. Chui, and H. Epler (1969) An ultrastructural study of early morphogenetic events during the establishment of fetal hepatic erythropoiesis. J. Cell Biol. 40:343-365.

Rostas, J. A. P., P. T. Kelly, and C. W. Cotman (1977) The identification of membrane glycocomponents in polyacrylamide gels: A rapid method using ${ }^{125} \mathrm{I}$-labeled lectins. Anal. Biochem. 80: 366-372.

Russell, E. S., and S. E. Bernstein (1966) Blood and blood formation. In Biology of the Laboratory Mouse, E. L. Green, ed., p. 351, McGrawHill Book Co., New York.

Schachner, M. (1979) Cell surface antigens of the nervous system. Curr. Top. Dev. Biol. 13: 259-279.

Schachner, M. (1982) Cell type-specific surface antigens in the mammalian nervous system. J. Neurochem. 39: 1-8.

Sharp, F. R., J. S. Kauer, and F. M. Shepherd (1975) Local sites of activity-related glucose metabolism in rat olfactory bulb during olfactory stimulation. Brain Res. 98: 596-600.

Sharp, F. R., J. S. Kauer, and G. M. Shepherd (1977) Laminar analysis of 2-deoxyglucose uptake in olfactory bulb and olfactory cortex of rabbit and rat. J. Neurophysiol. 40: 800-813.

Stallcup, W. B. (1981) The NG 2 antigen, a putative lineage marker: Immunofluorescent localization in primary cultures of rat brain. Dev. Biol. 83: 154-165.

Stewart, W. B., J. S. Kauer, and G. M. Shepherd (1979) Functional organization of rat olfactory bulb analyzed by the 2-deoxyglucose method. J. Comp. Neurol. 185: 715-734.

Stuhlfauth, I., and N. W. Seeds (1983) Cerebellar plasma membrane proteins and their antisera. Dev. Biol. 98: 80-100

Thommeson, G. (1983) Morphology, distribution, and specificity of olfactory receptor cells in salmonid fishes. Acta Physiol. Scand. 117 241-249.

Towbin, H., S. Theophil, and J. Gordon (1970) Electrophoretic transfer of proteins from polyacrylamide gels to nitrocellulose sheets: Procedure and some applications. Proc. Natl. Acad. Sci. U. S. A. 76: 43504354.

Vulliamy, T., S. Rattray, and R. Mirsky (1981) Cell-surface antigen distinguishes sensory and autonomic peripheral neurones from central neurones. Nature 291: 418-420.

Williams, C. A., and J. J. Marchalonis (1977) Hydrolysis with pepsin. In Methods in Immunology and Immunochemistry, C. A. Williams and M. W. Chase, eds., Vol. 1, pp. 422-423, Academic Press, Inc., New York. 